\title{
A new glacier inventory on southern Baffin Island, Canada, from ASTER data: II. Data analysis, glacier change and applications
}

\author{
Frank PAUL, Felix SVOBODA
}

\author{
Department of Geography, University of Zürich-Irchel, Winterthurerstrasse 190, CH-8057 Zürich, Switzerland \\ E-mail: frank.paul@geo.uzh.ch
}

\begin{abstract}
Despite its large area covered by glaciers and ice caps, detailed glacier inventory data are not yet available for most parts of Baffin Island, Canada. Automated classification of satellite data could help to overcome the data gaps. Along-track stereo sensors allow the derivation of a digital elevation model (DEM) and glacier outlines from the same point in time, and are particularly useful for this task. While part I of this study describes the remote-sensing methods, in part II we present an analysis of the derived glacier inventory data for $\mathbf{6 6 2}$ glaciers and an application to glacier volume and volume-change calculations. Among other things, the analysis reveals a mean glacier elevation of $990 \mathrm{~m}$, with a weak dependence on aspect and a close agreement of the arithmetic mean with the statistical mean elevation as derived from the DEM. A strong scatter of mean slope is observed for glaciers $<1 \mathbf{k m}^{2}$, and the derived glacier thickness differs by a factor of two for glaciers of the same size. For the period from about 1920 to 2000 the relative area change is $\mathbf{- 1 2 . 5 \%}$ (264 glaciers), with a strong dependence on glacier size. Mean mass loss as derived from volume changes is about $-0.15 \mathrm{~m}$ w.e. $\mathrm{a}^{-1}$.
\end{abstract}

\section{INTRODUCTION}

Detailed information on glaciers and ice caps in the Canadian Arctic is still rather limited, although basic data required for a glacier inventory (e.g. aerial photography) have been compiled (see Ommanney, 1980, 2009). Vector information (glacier outlines, elevation contour lines, etc.) has been digitized from historical topographic maps and is available for all of Baffin Island from a free internet site (http:// www.geogratis.ca). However, in most cases the map scale is $1: 250000$, which is too coarse for quantitative use in this study. Due to the large area covered by glaciers and ice caps in the Canadian Arctic (about 20\% of the global total), the potential contribution to global sea-level rise from this region might be large (Dyurgerov and Meier, 2005). Combined with the strong warming expected in the future for this region (e.g. Moritz and others, 2002; ACIA, 2004) and its already observed increased contribution to sea-level rise (Dowdeswell and others, 1997; Kaser and others, 2006) two kinds of datasets are required to improve the related calculations. First, there is an urgent demand for basic glacier inventory data such as location, size, length, minimum and maximum elevation (Kaser and others, 2006; Raper and Braithwaite, 2006; Rahmstorf, 2007). Secondly, there is need for detailed data on glacier fluctuations (i.e. changes in volume and length) from this sparsely sampled region (e.g. Dowdeswell and others, 1997; Oerlemans, 2005; WGMS, 2007).

As detailed in part I of this study (Svoboda and Paul, 2009), multispectral satellite data provide the most efficient means for glacier mapping over large and remote regions, since accurate and automated methods for glacier classification exist (e.g. Paul and others, 2002; Paul and Kääb, 2005; Andreassen and others, 2008). Combined with a digital elevation model (DEM) and automated processing within a Geographic Information System (GIS), the topographic glacier parameters mentioned above could be derived for each glacier (Kääb and others, 2002; Paul, 2007; Raup and others, 2007). Outside the coverage of the freely available DEM from the Shuttle Radar Topography Mission (SRTM) at 3" resolution (Farr and others, 2007), the required DEMs can be created from optical stereo sensors such as the Advanced Spaceborne Thermal Emission and Reflection Radiometer (ASTER) or Système Probatoire pour l'Observation de la Terre (SPOT) (e.g. Toutin 2006, 2008) using standard software packages. However, a careful evaluation of the DEM quality is mandatory. The region selected in this study lies outside the coverage of the SRTM DEM, and the DEM used here has been derived from the stereo bands of two sequential ASTER scenes (see Svoboda and Paul, 2009).

In this part II of the study we present a statistical analysis of the topographic glacier parameters derived from ASTER data, and changes in glacier size and length over time from the Little Ice Age (LIA) to 1975 and 2000 based on the Multispectral Scanner (MSS) and ASTER sensors. This work thus complements and extends a previous study in the same region (Paul and Kääb, 2005). Moreover, we illustrate how these datasets (topographic attributes and length changes) can be used to determine further parameters such as glacier volume and its change as estimated from cumulative length changes following Jóhannesson and others (1989). The latter approach is based on a simple but well-established method that works for large glacier ensembles (Hoelzle and others, 2003) and makes full use of the available topographic information from satellite stereo data.

\section{STUDY SITE AND DATASETS}

The study site has already been described in part I of the paper, so its major characteristics are only briefly repeated here. The region is located near the polar circle on the southeastern part of Baffin Island, called Cumberland Peninsula, and is covered by two ASTER scenes acquired on 13 August 2000 (Fig. 1). Part of this region and the region around Penny Ice Cap to the north has been investigated in a previous study (Paul and Kääb, 2005). The ice masses found in the region of this study are dominated by glaciers (mainly of valley, mountain and cirque type) and have only few ice caps with outlet glaciers. The glaciers used here for a more detailed analysis span a large range in size $\left(0.02-125 \mathrm{~km}^{2}\right)$ and are exposed to all directions. 


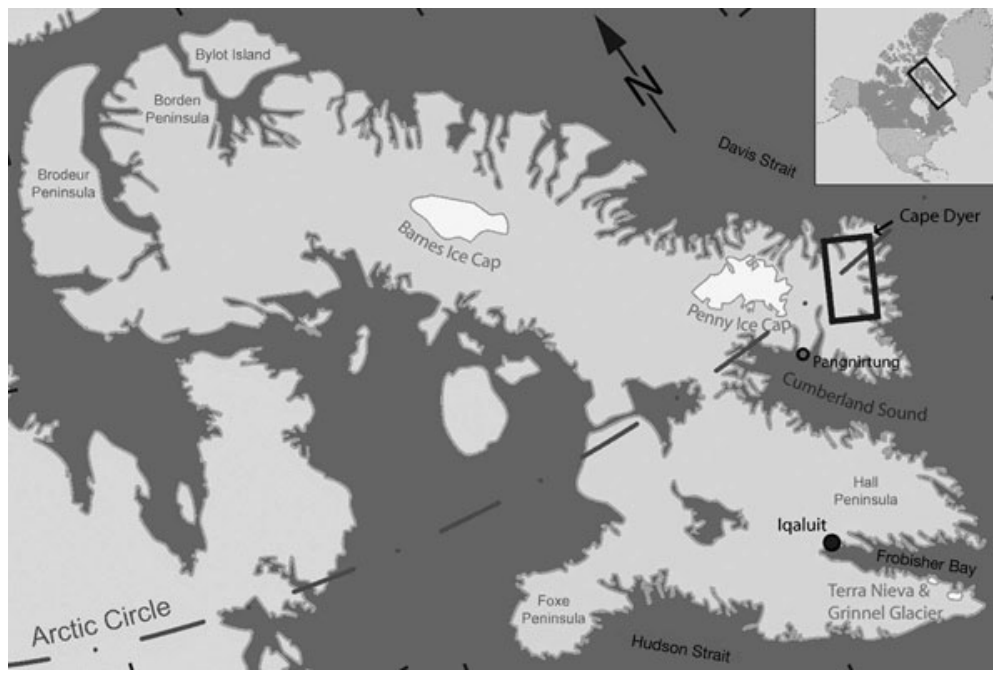

Fig. 1. Location of the study site (black square) on Baffin Island, Canada (modified from: http://atlas.gc.ca/).

Different glacier samples were selected for the inventory data and the change analysis. The two ASTER scenes from 2000 and the DEM derived from the same scenes provide the basic input for the inventory with 662 glaciers and ice caps (sample A). Contrast-enhanced false-colour composites (bands 4, 3 and 2 as RGB (red, green, blue)) from the two ASTER scenes have been used to delineate the Little Ice Age (LIA) maximum extent for a sample of 264 glaciers based on easily recognizable trimlines and moraines (sample B). We assume that the glaciers have been near their LIA maximum extent until the 1920s, but admit that this assumption is only weakly constrained (e.g. Dowdeswell, 1995; Grove, 2004). A sharp increase in temperature after 1920 as observed in West Greenland (Dowdeswell and others, 1997) is likely to have been the end of the LIA in this region. Glacier outlines derived from a Landsat MSS scene from 1975 were used as an additional time slice for the assessment of glacier length and area changes. Central flowlines for assessing glacier length and length change were digitized for 254 glaciers, of which 194 are used to calculate length changes from the LIA to 2000 (sample C). In this part of the paper, we present results from the glacier inventory from 2000 and a statistical analysis of changes in area and length for the LIA-1975-2000 period. The topographic glacier inventory parameters are also used to calculate a slope-dependent mean thickness and henceforth the volume for each glacier of sample B, as well as volume changes from the total glacier volumes and measured cumulative length changes (LIA-2000) for sample C.

\section{METHODS}

\section{Glacier inventory parameters}

While glacier area is provided automatically for each glacier polygon in a GIS, further topographic parameters for each glacier were calculated by combining glacier outlines with a DEM and DEM-derived parameters (Kääb and others, 2002; Paul and others, 2002; Paul, 2007). The latter include a slope grid as well as a sine and cosine grid (both derived from the aspect grid) which were used to calculate mean aspect. The slope and aspect grids are visualized for a subsection of the analysed scenes in Figure $2 \mathrm{a}$ and b, respectively. The slope grid illustrates that glaciers are generally flat and only the highest parts of tributaries are steeper. This has to be considered in the interpretation of mean glacier thickness.

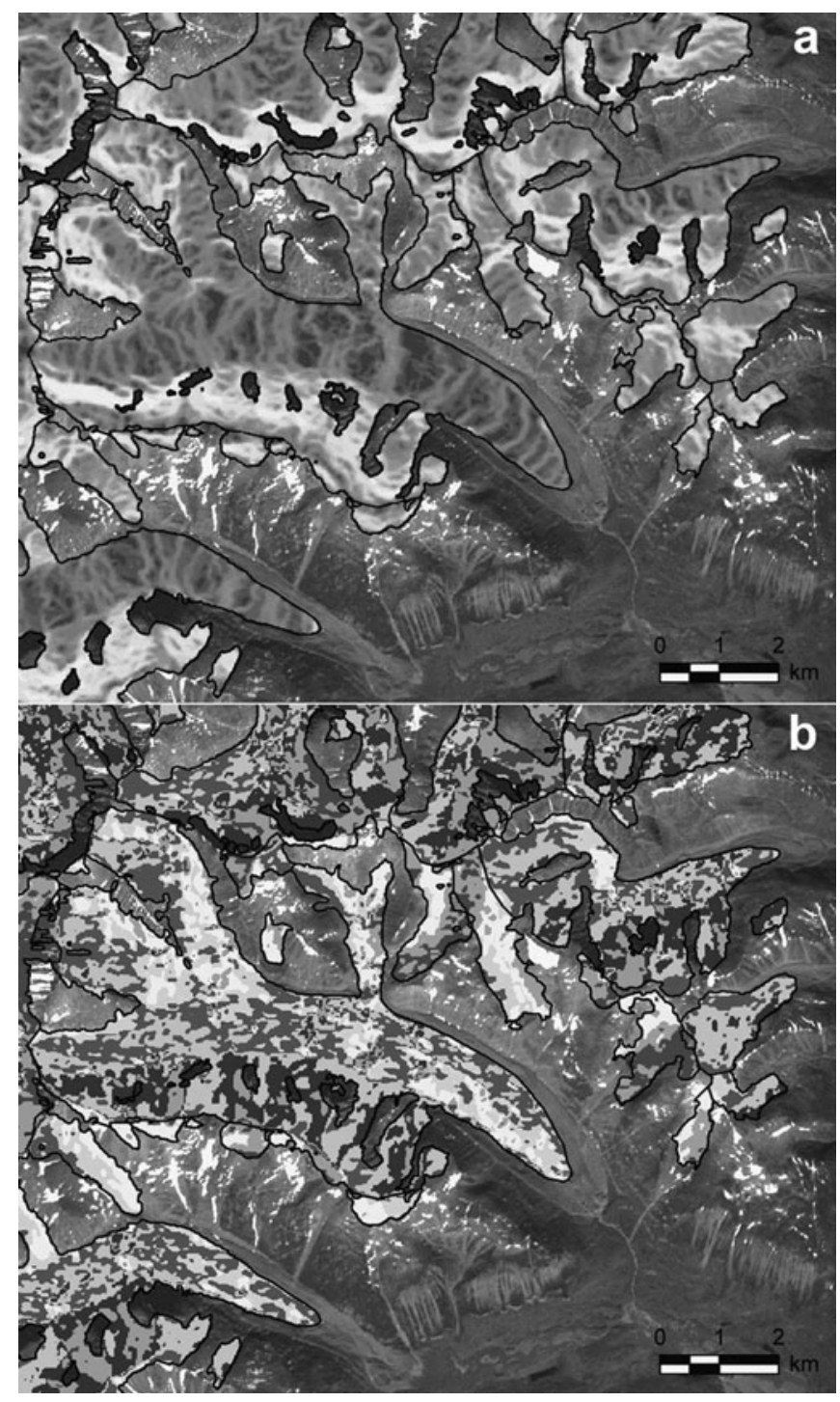

Fig. 2. Illustration of DEM-derived topographic parameters coded by greyscale. (a) Slope variability, ranging from low slopes (dark) to high slopes (white); and (b) aspect sectors for a subsection of the study site (see Fig. 3 for location). 


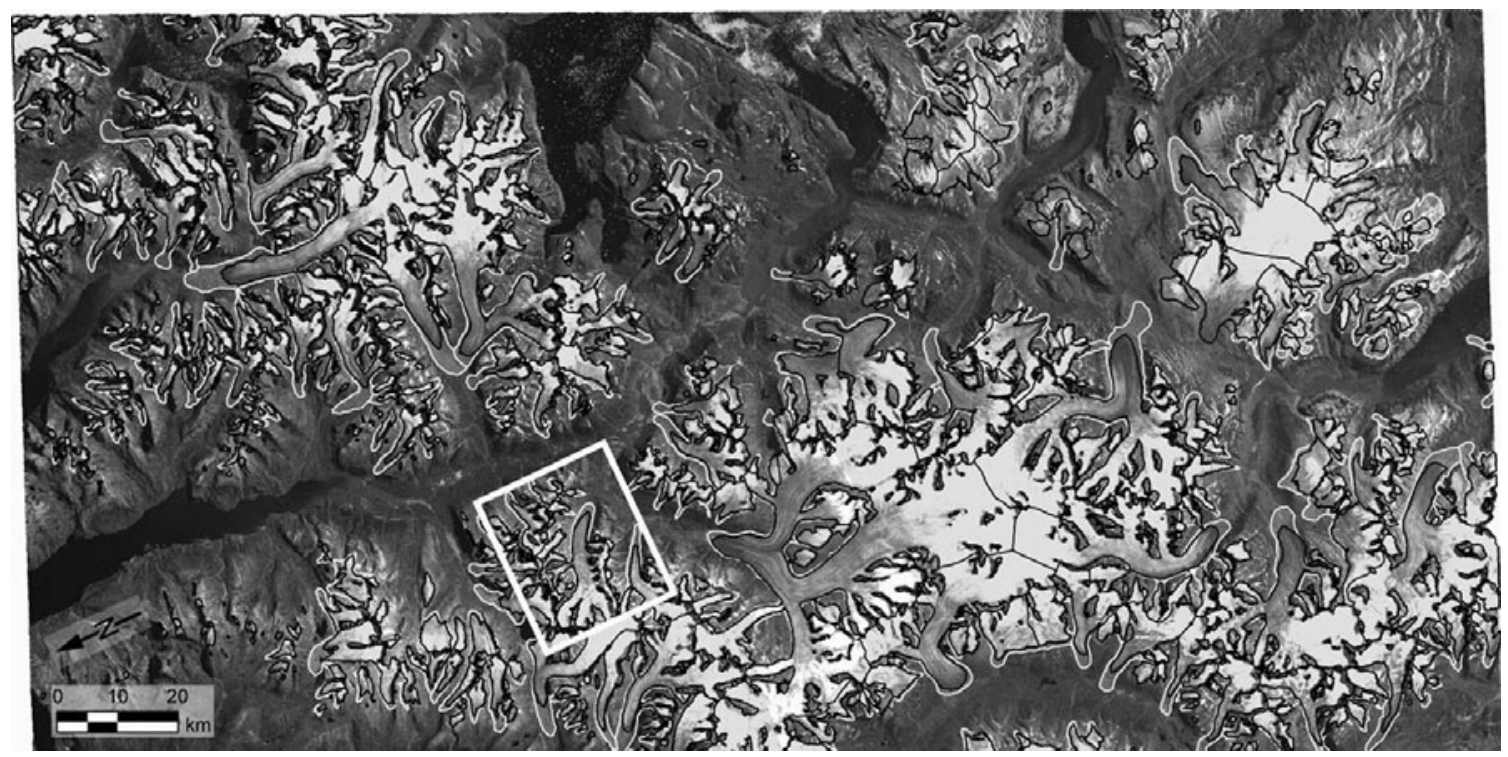

Fig. 3. Extent of glaciers and ice caps as mapped from ASTER for the year 2000 (black) by automated techniques and for the LIA (white) by manual trimline/moraine delineation. The location of the subset displayed in Figure 2 is indicated by a white square.

The small-scale variability of the aspect facets (Fig. 2b) demonstrates the irregular DEM surface as well as the fact that a mean aspect might have little climatological relevance for some glaciers. The statistical values (e.g. minimum, maximum, mean, standard deviation) are then calculated for each zone (i.e. coded glacier entity) from the respective value grid (DEM, slope, sine and cosine) following Paul and others (2002). Mean aspect is calculated from the arc tangent of the mean values of the respective sine and cosine grid in order to avoid wrong values for circular variables, and is expressed in a $0-360^{\circ}$ range as well as for the eight cardinal directions. Compared to the calculation of the mean aspect from the direction of the central flowline as applied in the World Glacier Inventory (WGI; WGMS, 1989), the grid-based approach considers all cells equally and is thus free from a bias due to human interpretation.

Hypsography (area-elevation distribution) is calculated for each glacier and the entire glacierized area in $50 \mathrm{~m}$ elevation bins from the ASTER-derived DEM and the glacier outlines from 2000. For comparison with calculations based on WGI data, mean slope is also calculated from the arc tangent of elevation range $\left(h_{\max }-h_{\min }\right)$ divided by glacier length. The latter is derived from central flowlines which were digitized manually because automated algorithms (e.g. based on the steepest downward gradient) generally fail in the ablation area where the curvature of the surface is convex. The central flowlines were digitized from the terminus to the highest point of the glacier and cross elevation contours perpendicularly. For glaciers in sample C they start at the LIA terminus position. In the case of a glacier that split into two or more parts after the LIA, flowlines were also digitized for the individual parts (see Svoboda and Paul, 2009). Due to the uncertainties in deriving the correct glacier length for glaciers with several compound basins or a complex topology, the slope value derived from length and elevation range could vary with the interpretation of glacier length.

Several possibilities exist to calculate the mean elevation of a glacier. When mean elevation is used as a proxy for the equilibrium-line altitude (ELA), it is useful to analyse these methods in more detail. At first, the arithmetic mean elevation $h_{\text {mean, a }}=\left(h_{\min }+h_{\max }\right) / 2$ is calculated. This mean elevation is available for tens of thousands of glaciers which have their values stored in the WGI (cf. Haeberli and Hoelzle, 1995). The second method is the statistical mean value $\left(h_{\text {mean,s }}\right)$ that is calculated by the GIS from summing up all elevation values within the glacier limits and dividing them by the number of cells. The third method of calculation is the area-weighted mean value $\left(h_{\text {mean,w }}\right)$ that results from the area-elevation distribution (hypsography) and divides the glacier into two equally sized parts. In mass-balance terms, it represents an accumulation-area ratio (AAR) of $50 \%$ and can be derived in the GIS as the median of all elevation values per glacier. In this study, all three methods of calculating mean values are applied and compared.

\section{Changes in glacier area and length}

The changes in glacier area are calculated directly by subtracting the total area values of the respective years for each glacier. In Figure 3 the mapped glacier extents from the year 2000 and the digitized LIA extents are illustrated for the entire study site. This provides a visual representation of glacier distribution, types and changes. Relative changes in area between the LIA and the 1975/2000 extent use the LIA extent as a base; the relative area changes between 1975 and 2000 refer to the 1975 extent (see Table 2, further below). For glaciers that have split since the LIA, the component parts of the former entity are added up. Length changes are calculated by intersecting the central flowline with the respective glacier outline. This approach was successful for the glaciers in this region, as complex geometric changes such as in the Alps (e.g. emerging rock outcrops) were less frequent (Paul, 2007). Length changes starting from the LIA maximum are generally calculated only for the main glacier. The maximum extent of tributaries that split from the main glacier after the LIA is in most cases not followed up to the LIA terminus position but only up to the former contact zone. Thus, for those glaciers the given length changes represent minimum estimates. As far as possible, doubtful cases were excluded from the sample. 


\section{Glacier volume and volume changes}

In this study, we make full use of the topographic information available for each glacier to calculate a slopedependent thickness following Haeberli and Hoelzle (1995). This allows us to obtain different glacier volumes for equally sized glaciers when they have different mean slopes. The approach is based on the shallow-ice approximation (SIA) which assumes ideal plasticity for ice (Paterson, 1994) and leads to a simple formulation for the basal shear stress $\tau(\mathrm{kPa})$ :

$$
\tau=d_{\mathrm{f}} f \rho \mathrm{g} \sin \alpha,
$$

where $d_{f}$ is the mean thickness along the central flowline $(\mathrm{m}), f$ is the form factor to account for varying glacier crosssections, $\rho$ is the density of ice $\left(\mathrm{kg} \mathrm{m}^{-3}\right), \mathrm{g}$ is the acceleration of gravity $\left(\mathrm{m} \mathrm{s}^{-2}\right)$ and $\alpha$ is the mean glacier slope $\left({ }^{\circ}\right)$. When this equation is used to calculate mean glacier thickness $d_{\mathrm{F}}$, $\tau$ must be obtained from other relations. An empirical approximation which relates basal shear stress to the elevation range $\Delta h$ and mass turnover $\mathrm{d} b / \mathrm{d} t$ of a glacier is proposed by Haeberli (1991). Here we use a regression fitted to the measured values of continental-type glaciers from that study,

$$
\tau=0.005+\Delta h-0.3 \Delta h^{2},
$$

and use an upper limit for $\tau$ of $1.5 \mathrm{kPa}$ for glaciers with $\Delta h>1.6 \mathrm{~km}$. The form factor $f$ is assumed to be 0.8 (a typical value for valley glaciers) and the same for all glaciers. Mean slope is taken from the DEM. The obtained mean thickness along the central flowline $d_{\mathrm{f}}$ is converted to mean glacier thickness $d_{\mathrm{F}}$ by multiplying $d_{\mathrm{f}}$ with a correction factor $k$, which is $\pi / 4$ for an assumed semielliptical glacier cross-section. Glacier volume is then obtained from $V=S k d_{\mathrm{f}}$, where $S$ is surface area $\left(\mathrm{km}^{2}\right)$. According to Maisch (1981), the variability of the derived thickness values is about $\pm 30 \%$.

Volume changes between the LIA and the 2000 extent are also derived from cumulative length changes in this period following Jóhannesson and others (1989). The method has been applied successfully by Hoelzle and others (2003) for glaciers in the Alps. In a first step, a mean mass-balance change is calculated which is then multiplied by the mean glacier size in that period to obtain the volume change. The method relates the changes in glacier length between two steady states to a corresponding shift (step change) in the ELA after full dynamic response. For continuity reasons, the added mass $\delta b$ over the total length $L_{0}$ has to be removed by ablation at the glacier tongue $\left(b_{t}\right)$ over the length change $\delta L$. This gives $\delta b=b_{\mathrm{t}}\left(\delta L / L_{0}\right)$, with the mean mass balance $\langle b\rangle=\delta b / 2$. While $L_{0}$ and $\delta L$ are taken from the glacier inventory, the balance at the tongue $b_{\mathrm{t}}$ is calculated from a mass-balance gradient $\mathrm{d} b / \mathrm{d} h$ and the elevation range of the ablation area: $b_{\mathrm{t}}=(\mathrm{d} b / \mathrm{d} h)\left(h_{\text {mean,a }}-h_{\text {min }}\right)$. For this region near the polar circle, $\mathrm{d} b / \mathrm{d} h$ is fixed to a value of $0.3 \mathrm{~m}$ w.e. $\left(100 \mathrm{~m}^{-1}\right) \mathrm{a}^{-1}$ which has been measured for Decade Glacier, Baffin Island, under steady-state conditions (PSFG, 1973).

Strictly speaking, the approach is only valid between two steady states, and the response time of the glaciers must be smaller than or equal to the considered time period (Jóhannesson and others, 1989). Here we assume that glacier retreat started around 1920 and thus have an 80 year period to consider. While this is too short for a full dynamic response for most of the larger glaciers, we found it worth testing nevertheless, as it should be valid for most glaciers in
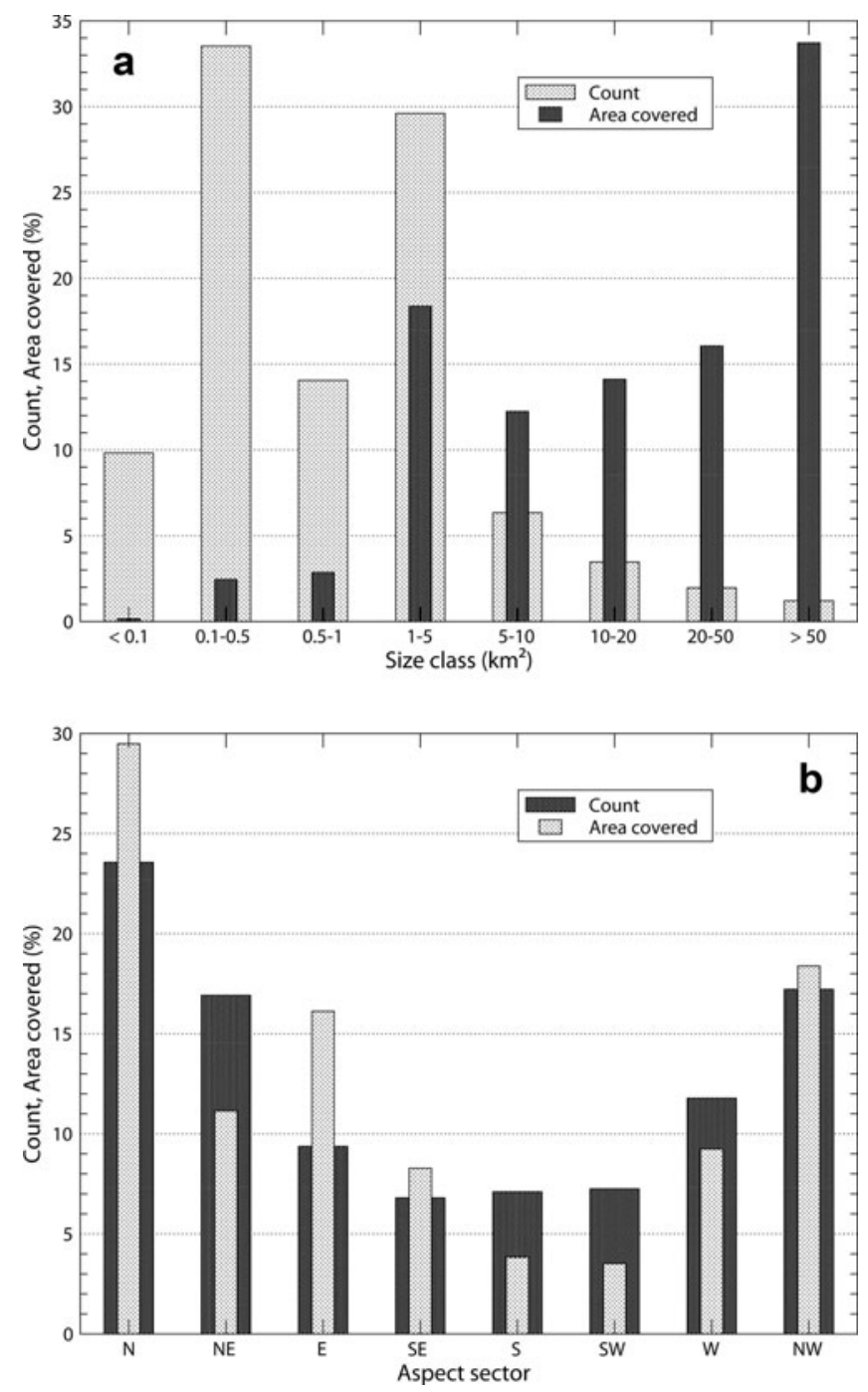

Fig. 4. Glacier count and area covered versus (a) size class and (b) aspect sector for sample A.

sample $\mathrm{C}$. The cumulative volume change $\Delta V$ is then calculated from the mean mass balance $\langle b\rangle$ (i.e. the mean thickness change), the mean glacier area of both points in time $\left(S_{1}, S_{2}\right)$ and the time period $\Delta t$ (80 years):

$$
\Delta V=\langle b\rangle\left[\left(S_{1}+S_{2}\right) / 2\right] \Delta t .
$$

\section{RESULTS}

\section{Glacier inventory parameters}

The following glacier parameters are available from the attribute table of each glacier for the year 2000: code, WGI code (where it could be assigned), latitude/longitude, area, minimum/maximum/mean elevation, length, mean slope and aspect (both with standard deviation) and mean thickness. This allows several parameters to be combined for a more detailed characterization of the glacier sample. Figure 4a shows a histogram of the count and area covered versus size class (see Table 1 for values). Nearly $90 \%$ of the 664 glaciers in this sample (A) are smaller than $5 \mathrm{~km}^{2}$ and they cover $<25 \%$ of the total area $\left(2416 \mathrm{~km}^{2}\right)$, whereas the eight largest glaciers larger than $50 \mathrm{~km}^{2}(1 \%$ by number) cover $33 \%$ of the area. Glaciers from 1 to $10 \mathrm{~km}^{2}$ and from 10 to $50 \mathrm{~km}^{2}$ each cover $30 \%$ of the area. Figure $4 \mathrm{~b}$ shows a histogram of the count and area covered in each aspect sector. The distribution is dominated by glaciers facing 
Table 1. Partition of count and area per size class and per aspect sector absolute and relative part for sample $A$

\begin{tabular}{|c|c|c|c|c|c|c|c|c|c|}
\hline \multirow{2}{*}{$\begin{array}{l}\text { Size class } \\
\mathrm{km}^{2}\end{array}$} & \multicolumn{2}{|c|}{ Count } & \multicolumn{2}{|c|}{ Area } & \multirow[t]{2}{*}{ Aspect } & \multicolumn{2}{|c|}{ Count } & \multicolumn{2}{|c|}{ Area } \\
\hline & & $\%$ & $\mathrm{~km}^{2}$ & $\%$ & & & $\%$ & $\mathrm{~km}^{2}$ & $\%$ \\
\hline$<0.1$ & 65 & 9.82 & 3.8 & 0.16 & North & 156 & 23.56 & 712.2 & 29.48 \\
\hline $0.1-0.5$ & 222 & 33.53 & 59.5 & 2.46 & Northeast & 112 & 16.92 & 269.1 & 11.14 \\
\hline $0.5-1$ & 93 & 14.05 & 69.1 & 2.86 & East & 62 & 9.37 & 389.5 & 16.12 \\
\hline $1-5$ & 196 & 29.61 & 443.9 & 18.38 & Southeast & 45 & 6.80 & 200.0 & 8.28 \\
\hline $5-10$ & 42 & 6.34 & 295.7 & 12.24 & South & 47 & 7.10 & 92.8 & 3.84 \\
\hline $10-20$ & 23 & 3.47 & 341.1 & 14.12 & Southwest & 48 & 7.25 & 85.0 & 3.52 \\
\hline $20-50$ & 13 & 1.96 & 387.9 & 16.06 & West & 78 & 11.78 & 223.2 & 9.24 \\
\hline$>50$ & 8 & 1.21 & 814.4 & 33.72 & Northwest & 114 & 17.22 & 444.1 & 18.38 \\
\hline Total & 662 & 100 & 2416 & 100 & & 662 & 100 & 2416 & 100 \\
\hline
\end{tabular}

towards the three northern sectors, regardless of whether the count or the area covered is considered. When glaciers $>50 \mathrm{~km}^{2}$ are discounted, the preference for the northern sectors in respect to the area covered is much less pronounced.

The dependence of mean elevation on aspect is depicted in Figure 5a. This figure also illustrates the higher abundance of north-facing glaciers. When mean values for the eight
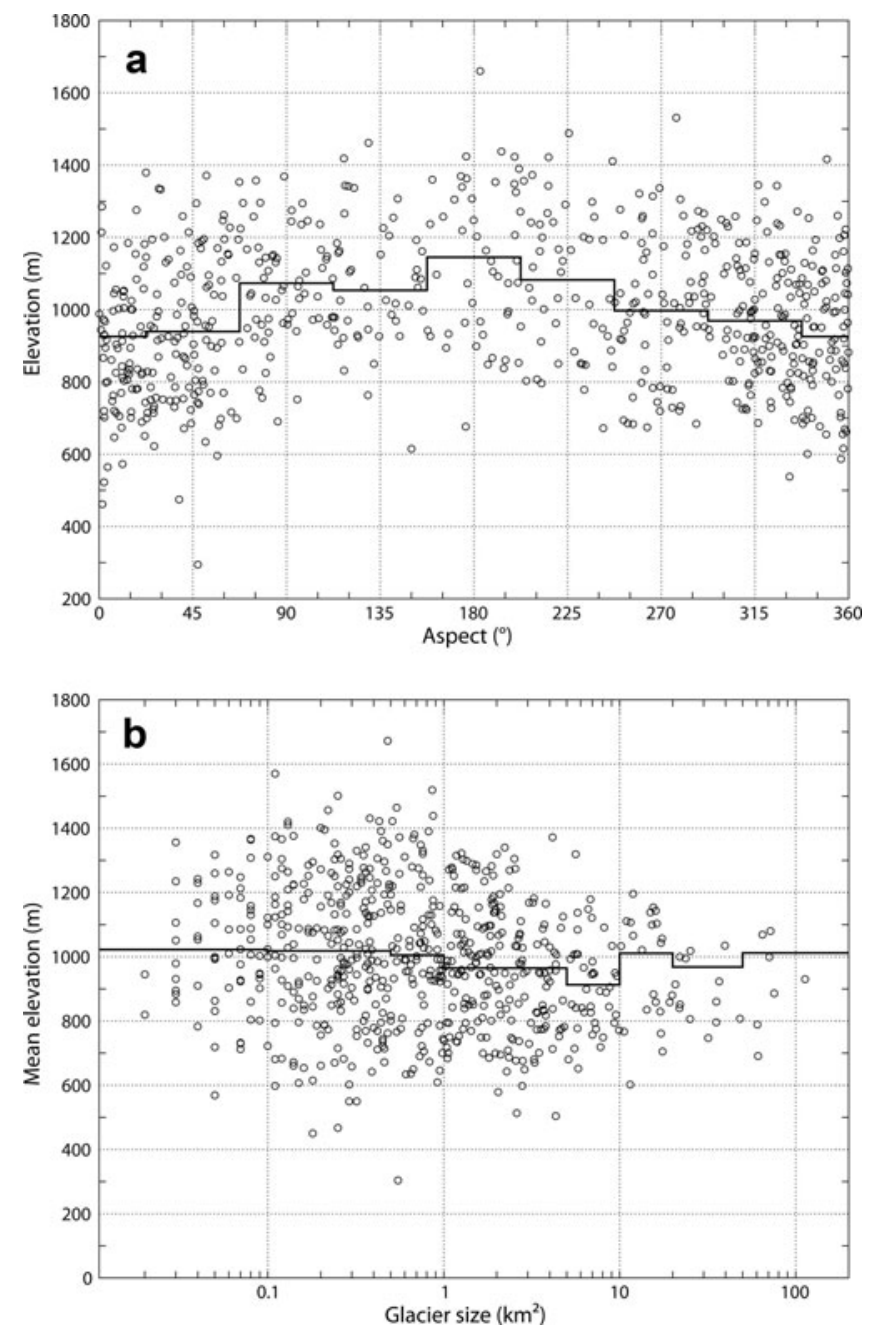

Fig. 5. (a) Mean glacier elevation versus aspect. The solid line gives mean values for the eight cardinal sectors. (b) Mean glacier elevation versus size. The solid line gives mean values for distinct size classes. sectors are computed, an increase in mean elevation of about $200 \mathrm{~m}$ from north to south is noted. This indicates that exposure to solar radiation influences glacier location, because the energy and mass balance of glaciers (and thus their growth or decay) is also determined by solar radiation (e.g. Evans, 2006). On the other hand, glacier size is not correlated with glacier mean elevation (992 $\mathrm{m}$ for the entire sample), but a high scatter is present (Fig. 5b). The scatter increases slightly towards smaller glaciers, which implies that local topographic characteristics become more important for the location of smaller glaciers.

In Figure 6a the dependence of mean slope on glacier size is depicted, revealing that larger glaciers tend to have lower mean slopes. However, the scatter towards smaller glaciers is large and a considerable number of small glaciers are comparably flat. This could be because some glaciers are situated in local topographic depressions (e.g. perennial snow banks). The large variability of mean slope for glaciers of the same size results in a related variability of mean glacier thickness up to a factor of two (Fig. 6b). The consideration of the slope-dependent thickness variability is in our opinion thus a clear improvement over twodimensional approaches that use planar information only to obtain glacier volume (Driedger and Kennard, 1986; Haeberli and others, 2008).

A comparison of mean slope, as calculated from zonal statistics using the DEM and from the arc tangent of glacier length divided by elevation range, is given in Figure 7a. A linear regression gives a correlation coefficient of 0.85 , with a regression slope of 0.999 and an intercept of -2.33 . This implies that the mean slope from the zonal statistics calculation is on average $2.3^{\circ}$ steeper, without any slopedependent trend. The outliers and the large scatter suggest that the mean slope derived from length and elevation range is subject to higher uncertainty. However, the comparably high correlation $(0.87$ when neglecting six outliers) confirms that the approach used by Haeberli and Hoelzle (1995) gives a reasonable approximation of the mean slope in most cases. The correlation of mean elevation as derived from zonal statistics $\left(h_{\text {mean,s }}\right)$ with the arithmetic mean elevation $\left(h_{\text {mean, },}\right)$ is depicted in Figure $7 \mathrm{~b}$. The correlation coefficient is comparably high $(r=0.97)$ and has only a slight trend (regression slope $=0.93$ ). This implies that $h_{\text {mean, a }}$ could indeed be used as a proxy for mean elevation.

A scatter plot displaying minimum and maximum elevation vs glacier size for individual glaciers is depicted in Figure 8a. Mean elevations for distinct size classes are 

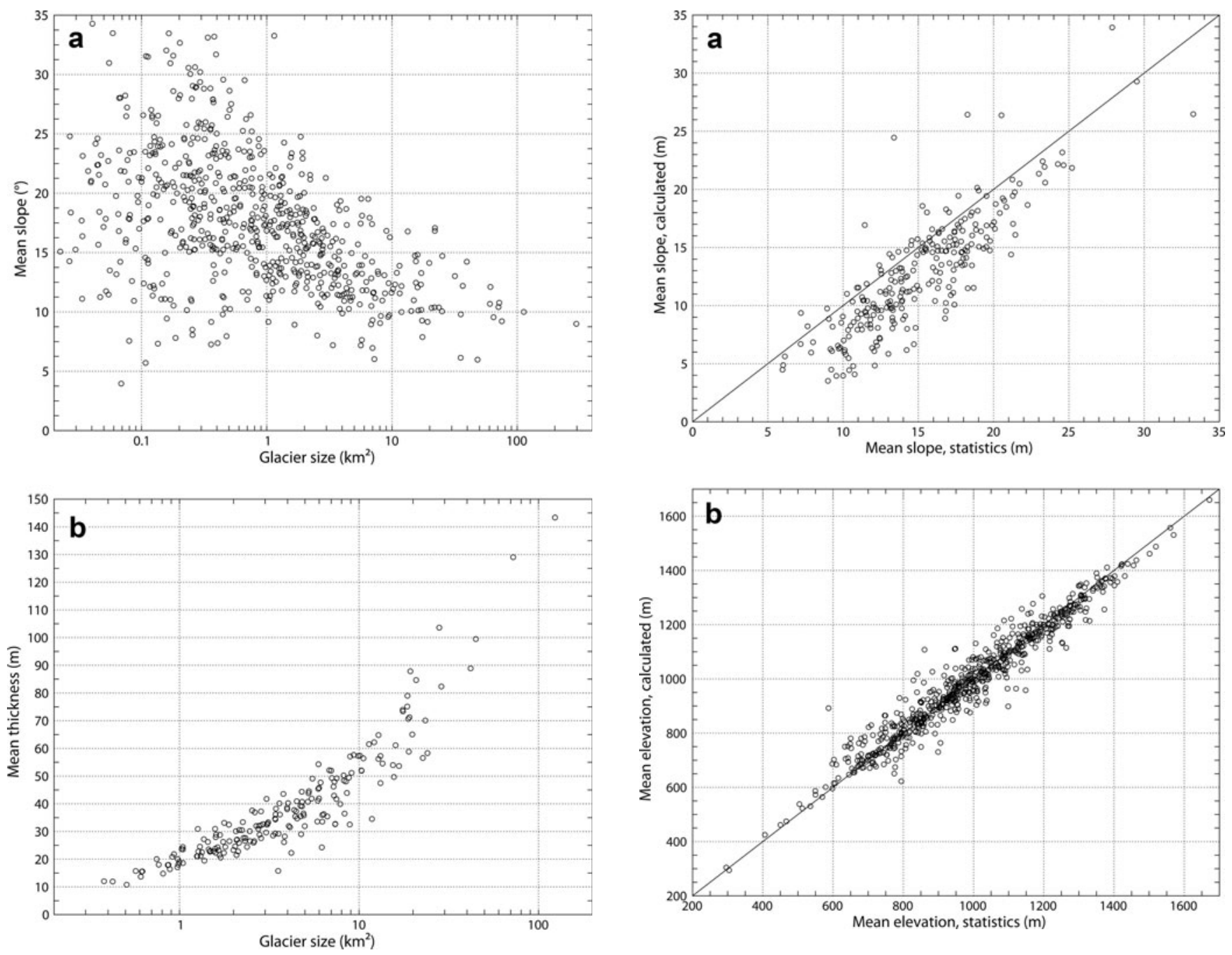

Fig. 6. (a) Mean slope versus glacier size for sample A. (b) Mean thickness versus glacier size for sample C.

Fig. 7. (a) Mean slope derived from DEM statistics versus mean slope derived from elevation range and length. (b) Mean elevation derived from DEM statistics $\left(h_{\text {mean,s }}\right)$ versus arithmetic mean elevation $\left(h_{\text {mean,a }}\right)$.

also included. While the scatter plot clearly reveals an increase (decrease) in mean maximum (minimum) elevation with glacier size, it also illustrates that the scatter of values for glaciers $<5 \mathrm{~km}^{2}$ is high and that glaciers $<1 \mathrm{~km}^{2}$ could reach far down (Fig. 5b). Figure $8 \mathrm{~b}$ illustrates the areaelevation distribution for nine selected larger glaciers. While a large portion of the ice cover is situated between 600 and $1400 \mathrm{~m}$ a.s.I., the large variability of the hypsographic curves indicates that the response of individual glaciers in this region to the same climatic forcing might be different.

\section{Changes in glacier area, length and other parameters}

Area changes between the LIA extent and 2000 have been calculated for 264 glaciers (sample B). The mean relative area change for the LIA-2000 period is $-12.5 \%$ ( $-7.3 \%$ until $1975)$, which gives a $55 \%$ increase in the total area loss rate for the period since 1975. The related scatter plot (Fig. 9a) reveals a dependence of the change on glacier size (increasing loss towards smaller glaciers), with a limited increase in scatter towards smaller glaciers. Table 2 lists the mean values per size class and time period.

Length changes from the LIA maximum extent to the year 2000 extent range from one pixel to $3.3 \mathrm{~km}$ (Fig. 9b). A linear regression through the data points shows a good correlation

between length changes and original glacier length $(r=0.79)$. This confirms the general rule and long-term observations that longer glaciers have stronger length changes (e.g. Jóhannesson and others, 1989; Hoelzle and others, 2003) and that averaging length changes over different-sized glaciers could be done for statistical purposes only. Keeping this in mind, the mean retreat rate for the sample analysed here is about $10 \mathrm{~m} \mathrm{a}^{-1}$, with a maximum of $35 \mathrm{ma}^{-1}$ and with little change of the rates in the two investigated periods. Similar retreat rates (about $10-30 \mathrm{~m} \mathrm{a}^{-1}$ ) have been measured for glaciers in the European Alps (e.g. Hoelzle and others, 2003). It seems that this region is nearly free from surging glaciers (e.g. absent looped moraines) which occur quite often in the Canadian High Arctic (Copland and others, 2003) or on neighbouring Disko Island, Greenland (Yde and Knudsen, 2007).

The change in mean and minimum glacier elevation was calculated using glacier outlines mapped from the LIA moraines and year 2000 outlines combined with the ASTER DEM. For a glacier geometry in balance with climate, one proxy that can be used to estimate the steady-state ELA $\left(E A_{0}\right)$ is the arithmetic mean elevation (e.g. Haeberli and Hoelzle, 1995). This is because $h_{\text {mean,a }}$ divides a glacier into two parts, where the upper part is generally somewhat larger 

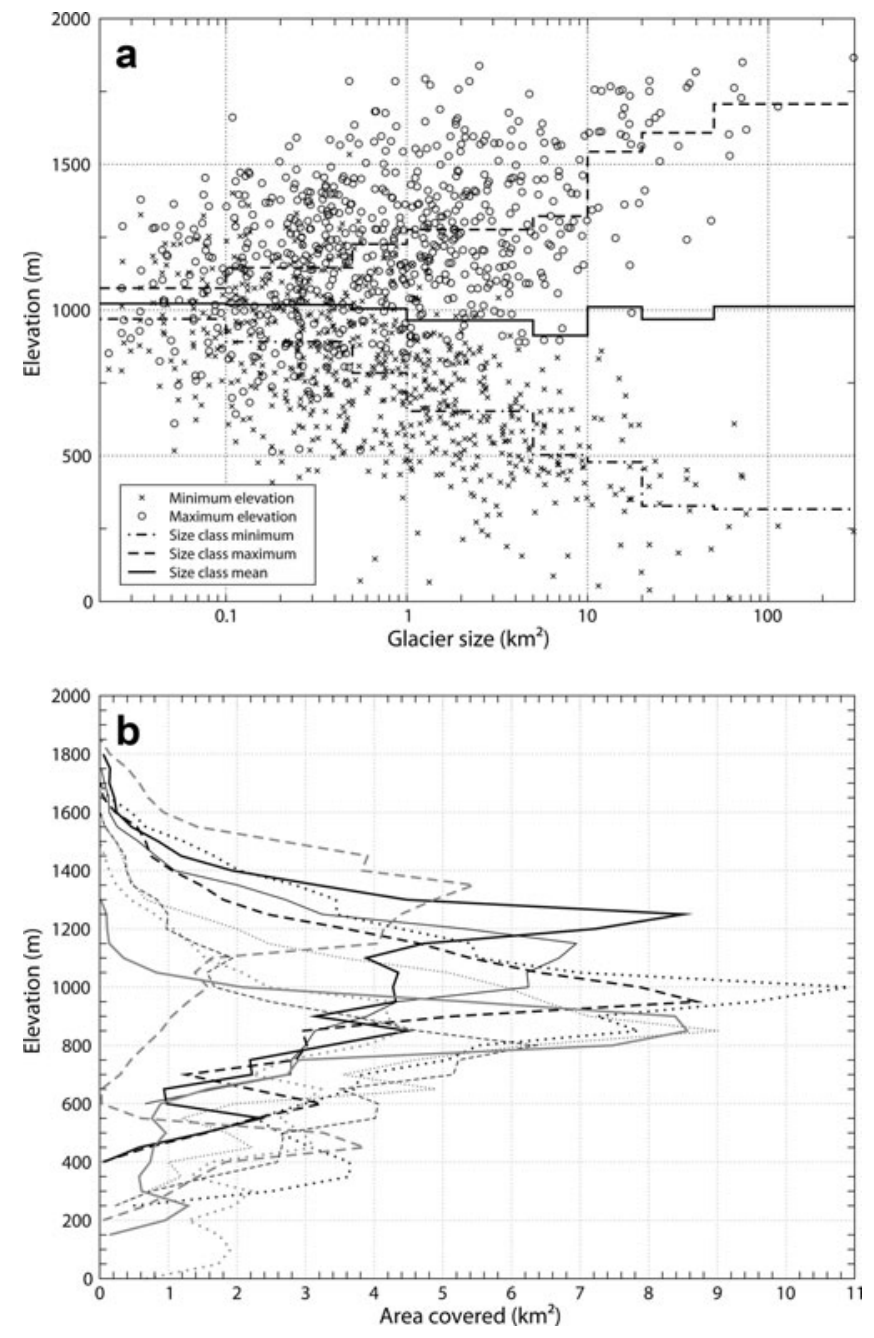

Fig. 8. (a) Minimum and maximum elevation for each glacier (sample A) versus glacier size. Mean values for discrete size classes are also given. (b) Area elevation distribution in $50 \mathrm{~m}$ bins for nine selected larger glaciers.

than the lower part, reflecting typical steady-state accumulation-area ratios $\left(\mathrm{AAR}_{0}\right)>0.5$ (e.g. Braithwaite and Raper, 2007; WGMS, 2007). On average, mean glacier elevation in this region increased between the LIA extent and 2000 from 880 to $926 \mathrm{~m}(+46 \mathrm{~m})$. Based on an assumed overall $1-1.5^{\circ} \mathrm{C}$ increase of mean annual air temperature since the LIA in the Arctic (ACIA, 2004), the ELA should have risen by at least $150 \mathrm{~m}$. Although mean elevation is only a proxy for ELA, it can be concluded that glacier geometries are not yet in balance with the current climate and most glaciers will continue to shrink and retreat (which will further increase their mean elevation). Between two steady states and for purely geometrical reasons, the change in minimum elevation is twice as large as the change in $h_{\text {mean, a }}$ (assuming that maximum elevation is constant). This allows approximation of the change in mean elevation between two steady states, from the change in minimum elevation. For example, within sample $C$, the mean minimum elevation increased

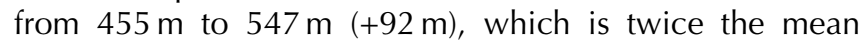
elevation change.

\section{Glacier volume and volume change}

Total glacier volume was calculated with the method described above for the LIA and the year 2000, based on
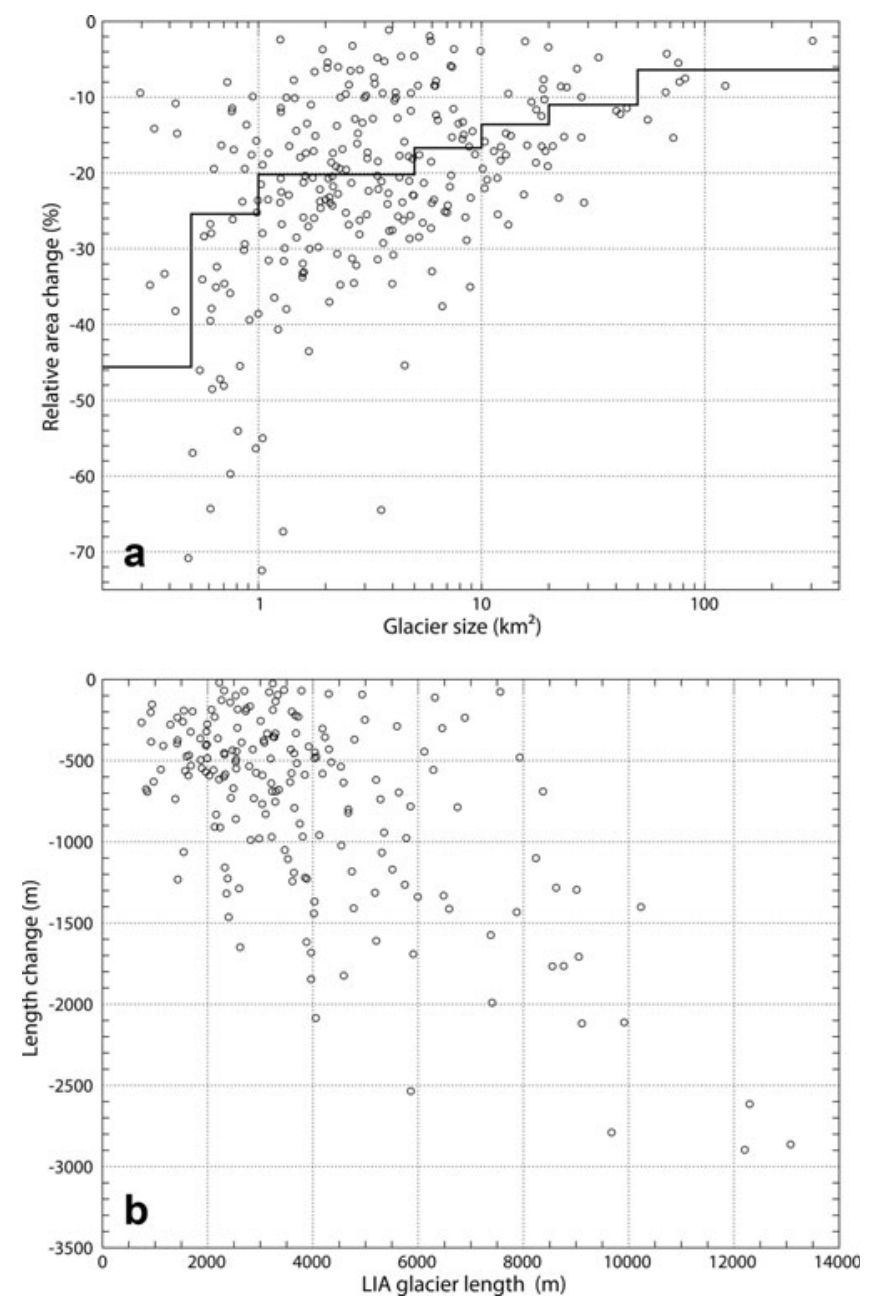

Fig. 9. (a) Relative change in glacier area versus glacier size for the period LIA-2000. Mean values for discrete size classes are also given. (b) Absolute length change versus glacier length at the LIA maximum (sample C).

the respective glacier sizes and the calculated glacierspecific mean thickness. The strong spread (up to $\pm 50 \%$ ) of mean thickness for glaciers of the same size is depicted in Figure $6 \mathrm{~b}$ for the sample (C) of 194 glaciers. The total glacier volume calculated from the LIA extent $\left(1369 \mathrm{~km}^{2}\right.$ in total) is $65.96 \mathrm{~km}^{3}$, while it is $49.74 \mathrm{~km}^{3}$ for the year 2000 extent $\left(1145 \mathrm{~km}^{2}\right)$. This gives a total volume loss of $16.22 \mathrm{~km}^{3}$ in approximately 80 years over a mean surface area of $1257 \mathrm{~km}^{2}$, or $-0.22 \mathrm{~m}$ w.e. $\mathrm{a}^{-1}$. The mean volume change was also derived from cumulative mass changes as described above. Because the year 2000 glacier length of several larger glaciers is presumably not in balance with the current climate, further retreat is expected to occur for these glaciers. For this reason, the length-change method might underestimate the mean mass loss when compared with the other method. Indeed, the mean mass loss $\langle b\rangle$ derived from the length-change method for sample $C$ is $-0.11 \mathrm{mwe}^{-1}$, or $-11.73 \mathrm{~km}^{3}$ in total. When a 100 year period is assumed for the change period, the first method gives a mass change of -0.18 mw.e. $\mathrm{a}^{-1}$ and the second method a total volume change of $13.2 \mathrm{~km}^{3}$, so both results come closer. In any case, total volume has decreased by about $13-24 \%$ which is in the range of the respective relative area change $(-16 \%)$ for this sample. 
Table 2. Glacier extent for LIA ( 1920), 1975 and 2000 along with absolute and relative changes in area for eight size classes and sample B during the periods $P_{1}$ (LIA-1975), $P_{2}(1975-2000)$ and $P_{3}$ (LIA-2000)

\begin{tabular}{|c|c|c|c|c|c|c|c|c|c|c|}
\hline \multirow{3}{*}{$\begin{array}{l}\text { Size class } \\
\mathrm{km}^{2}\end{array}$} & \multirow[t]{3}{*}{ Count } & \multicolumn{3}{|c|}{ Glacier area } & \multicolumn{3}{|c|}{ Absolute area change } & \multicolumn{3}{|c|}{ Relative area change } \\
\hline & & LIA & 1975 & 2000 & $P_{1}$ & $P_{2}$ & $P_{3}$ & $P_{1}$ & $P_{2}$ & $P_{3}$ \\
\hline & & $\mathrm{km}^{2}$ & $\mathrm{~km}^{2}$ & $\mathrm{~km}^{2}$ & $\mathrm{~km}^{2}$ & $\mathrm{~km}^{2}$ & $\mathrm{~km}^{2}$ & $\%$ & $\%$ & $\%$ \\
\hline $0.1-0.5$ & 29 & 18 & 12 & 10 & -5.9 & -2.5 & -8.3 & -32.1 & -19.8 & -45.6 \\
\hline $0.5-1$ & 32 & 32 & 28 & 24 & -4.0 & -4.2 & -8.2 & -12.3 & -15.0 & -25.4 \\
\hline $5-10$ & 37 & 313 & 283 & 260 & -29.7 & --22.6 & -52.2 & -9.5 & -8.0 & -16.7 \\
\hline $10-20$ & 21 & 368 & 337 & 318 & -30.4 & -19.6 & -50.0 & -8.3 & -5.8 & -13.6 \\
\hline $20-50$ & 11 & 368 & 349 & 328 & -19.4 & -21.0 & -40.5 & -5.3 & -6.0 & -11.0 \\
\hline$>50$ & 8 & 870 & 838 & 814 & -32.6 & -23.5 & -56.1 & -3.7 & -2.8 & -6.4 \\
\hline Total & 264 & 2360 & 2187 & 2066 & -172.4 & -121.6 & -294.0 & -7.3 & -5.6 & -12.5 \\
\hline Decadal & & & & & 31.35 & 48.64 & 36.75 & -1.33 & -2.22 & -1.56 \\
\hline
\end{tabular}

\section{DISCUSSION}

The possibility of deriving glacier outlines and a DEM from the same point in time from ASTER satellite data is a very efficient means to generate detailed glacier inventory data in regions of complex topography with most glaciers $<1 \mathrm{~km}^{2}$ in size. This was also demonstrated in a recent study by Racoviteanu and others (2008) using the SPOT 5 sensor. The semi-automatic GIS-based calculation of topographic parameters (e.g. mean slope, aspect and hypsography) from zonal statistics is less biased by human interpretation and has the advantage of being reproducible. Glacier-specific estimates of glacier volume could be obtained from these topographic parameters using a mainly slope-dependent mean thickness. Considering that at many sites in the study region LIA glacier extents could be mapped from wellpreserved trimlines and moraines, this type of analysis allows us to include a temporal dimension and to calculate volume changes from cumulative length changes for a large sample (>100) of glaciers. Thus, it is possible to derive some value-added products for a glacier inventory from a single ASTER scene. Of course, there is little control on the quality of the derived parameters (e.g. mean glacier thickness) unless field measurements are available for validation. Nevertheless, considering the approaches currently used to estimate the sea-level rise contribution from melting glaciers and ice caps on a global scale, it is assumed that these new data could make a valuable contribution to the state of knowledge (e.g. Raper and Braithwaite, 2006).

The major drawback of ASTER (or SPOT) scenes is the small region covered $(60 \mathrm{~km}$ by $60 \mathrm{~km}$ instead of the $180 \mathrm{~km}$ by $185 \mathrm{~km}$ from Landsat). In heavily glacierized regions such as the Arctic, this requires large amounts of scenes to be processed and mosaicked for glacier mapping. Collection of ground control points and accurate orthorectification of the scenes is another important and time-consuming issue that applies to ASTER as well as some other sensors. It has ceased to apply to Landsat, however, as already orthorectified scenes from the entire archive are now available for free (US Geological Survey, http://pubs.usgs.gov/fs/2008/3091/pdf/ fs2008-3091.pdf). With the ASTER global DEM (GDEM) now available, it should be feasible to produce a more or less complete and detailed global glacier inventory.

Regarding the statistical properties obtained, the size class distribution derived by automated techniques allows us to consider the entire spectrum of glacier sizes without neglecting small (mostly debris-free) glaciers. The frequency distribution obtained here (Fig. 4a) confirms a bias towards the smallest glaciers which is also known from other regions with complete inventories. Glaciers ranging from 1 to $5 \mathrm{~km}^{2}$ contribute $27 \%$ to the total area loss from the LIA extent to 2000. This is $40 \%$ more than the contribution of large glaciers $\left(>50 \mathrm{~km}^{2}\right)$ which contribute $19 \%$. From this point of view, an exclusive focus on the largest glaciers will give misleading results on area change, as has been shown in previous studies (e.g. Paul and others, 2004). The small variability of mean elevation for glaciers of different size classes (Fig. 8a) indicates that glaciers in this region face similar climatic conditions regarding the precipitation regime (assuming that mean elevation is closely related to the amount of precipitation; see Ohmura and others, 1992). However, the large scatter in mean elevation of individual glaciers (Fig. 4b) implies that favourable glacier locations are also controlled by local topographic characteristics. This is also obvious from the dependence of mean elevation on aspect (see Fig. 4a). While there is a large overall scatter, the increase of the mean elevation for discrete aspect sectors towards south-facing glaciers indicates that exposure to solar radiation may have a stronger influence here than in other Arctic regions.

The relative area changes (LIA-2000) for individual glaciers display an increasing spread towards smaller glaciers in a scatter plot (Fig. 9a). This has also been observed in several other studies (e.g. Paul and others, 2004; Granshaw and Fountain, 2006; Andreassen and others, 2008; Racoviteanu and others, 2008) and indicates that the behaviour of such small glaciers is somewhat decoupled from the climate forcing. However, it could also be related to the decreased accuracy of the outline mapping when seasonal snow cover hides parts of the perimeter. We found such a more pronounced scatter of the relative area changes for the period 1975-2000 where the higher uncertainty of the glacier outlines is due to the mapping from the MSS sensor and less optimal snow conditions in the scene (see Svoboda and Paul, 2009). On the other hand, the region to the north of this study site (around Penny Ice Cap) displayed a smaller and nearly size-independent scatter (Paul and Kääb, 2005). Currently, we have no explanation for this difference. 
The calculated glacier volumes have, of course, a high uncertainty for individual glaciers. In a study that compared reconstructed Late-glacial glacier thickness to values derived from a regression through the same data points, deviations of $\pm 30 \%$ were observed (Maisch, 1981). However, we know from an unpublished previous study that the values derived by the method described by Haeberli and Hoelzle (1995) are in close agreement with other volume-calculation approaches. Given the large scatter of mean slope values for glaciers of the same size (Fig. 6a), we think that the calculation of glacier volume from a slope-dependent mean thickness is one step closer to reality than one-dimensional approaches, as we can derive different volumes for glaciers of the same size. However, as long as field data are missing for confirmation of the calculated values, they are only an approximation.

The good correlation between glacier length change and glacier length (Fig. 9b) implies that mean length changes for an entire region should not be compared directly to other regions where the glacier length distribution is different. However, in combination with a suitable (measured or modelled) mass-balance gradient, the cumulative length changes can be converted to a mean mass change (e.g. Hoelzle and others, 2003). Several assumptions were made to obtain the mean mass change in this study: (a) We assumed a constant retreat of all glaciers since 1920 which might not be the case for some of the smaller glaciers with response times shorter than 80 years. (b) We assumed that the glaciers in this region are not influenced by dynamic instabilities such as surging. This is common in the High Arctic (Copland and others, 2003) or on nearby Disko Island (Yde and Knudsen, 2007) and prevents the same scheme from being applied in the latter region (Citterio and others, 2009). (c) The applied massbalance gradient and regression used to calculate $\tau$ from the elevation range is certainly only valid for a mean of a larger sample, and individual glaciers might strongly deviate from this. In total, we estimate that the derived mean mass balance for this region and period could be in the range -0.1 to $-0.2 \mathrm{~m}$ we $\mathrm{a}^{-1}$, which is a somewhat stronger mass loss then expected for this Arctic region (with partly cold glaciers) during this period (Hoelzle and others, 2003). This could imply that the contribution of glacier melt from this region to global sea-level rise is already higher than previously assumed (e.g. Kaser and others, 2006; Meier and others, 2007).

When mean glacier thickness is calculated from mean slope, the DEM-derived slope is preferred (see Fig. 2a) because it considers specific glacier characteristics. However, when volume changes are calculated, the mean slope calculated from elevation range and length has to be used, as DEMs corresponding to the LIA glacier surface are generally not available. Slope values derived from the DEM are systematically higher than slope values derived from elevation range and glacier length (Fig. 7a). This results in a smaller mean glacier thickness for slope values derived from a DEM. The accuracy of the slope calculation algorithms has to be obtained by comparison with field data (which are not yet available for this region).

The mean elevation obtained from the DEM and calculated from the elevation range revealed nearly identical values (Fig. 7b). However, the area-weighted mean elevation was $62 \mathrm{~m}$ (LIA) and $47 \mathrm{~m}$ (2000) higher in the mean. This implies that the somewhat lower mean elevation from the DEM or the elevation range is a better proxy for an $\mathrm{AAR}_{0}$ of 0.6 than for a 0.5 value.

\section{CONCLUSION}

We have presented results from the new satellite-derived glacier inventory for the southernmost part of Baffin Island using two ASTER scenes from the year 2000. The DEM derived from the same scene was used to calculate topographic glacier inventory parameters on a glacier-byglacier basis. The spatial resolution of the ASTER sensor allows the mapping of trimlines and moraines indicating the LIA maximum extent. The two datasets were combined to derive additional parameters such as the specific volume of each glacier and the volume changes since the LIA. The statistical data of the inventory revealed a bias towards large glaciers: of the 664 analysed glaciers, only 8 glaciers are larger than $50 \mathrm{~km}^{2}$ but these cover one-third of the total area. The increase of mean elevation for south-facing glaciers and the preferred northern aspect indicates a marked influence of solar radiation on glacier mass balance and location. The high variability of the hypsographic curves for the largest glaciers implies that these glaciers may react differently to the same climate forcing (assuming that mass balance also depends on hypsography). The area loss for a subsample of 264 glaciers is $12.5 \%$ since the LIA maximum extent, which is small compared to the length changes which reach $3 \mathrm{~km}$. Several glaciers shorter than $4 \mathrm{~km}$ lost $50 \%$ of their LIA length and there is a good correlation between glacier length and length change. The derived mean mass loss of about $0.15 \mathrm{~m} \mathrm{a}^{-1}$ since the LIA is somewhat higher than expected for this Arctic region and time period. The change in mean glacier elevation since the LIA $(+50 \mathrm{~m})$ and calculated response times indicate that the glaciers in this region will retreat further and lose mass in the future.

\section{ACKNOWLEDGEMENTS}

We thank A. Racoviteanu and an anonymous reviewer for constructive comments and helpful suggestions. This study was funded by the European Space Agency project GlobGlacier (21088/07/I-EC) and has been performed within the framework of the Global Land Ice Measurements from Space (GLIMS) initiative. GLIMS also provided the ASTER imagery used in this study. The Thematic Mapper (TM) and MSS scenes were obtained from the Global Land Cover Facility (GLCF) at the University of Maryland.

\section{REFERENCES}

Andreassen, L.M., F. Paul, A. Kääb and J.E. Hausberg. 2008. Landsatderived glacier inventory for Jotunheimen, Norway, and deduced glacier changes since the 1930s. Cryosphere, 2(2), 131-145.

Arctic Climate Impact Assessment (ACIA). 2004. Impacts of a warming Arctic: Arctic Climate Impact Assessment. Cambridge, etc., Cambridge University Press.

Braithwaite, R.J. and S.C.B. Raper. 2007. Glaciological conditions in seven contrasting regions estimated with the degree-day model. Ann. Glaciol., 46, 297-302.

Citterio, M., F. Paul, A.P. Ahlstrøm, H.F. Jepsen and A. Weidick. 2009. Remote sensing of glacier change in West Greenland: acounting for the occurrence of surge-type glaciers. Ann. Glaciol., 50(53). (see paper in this issue).

Copland, L., M.J. Sharp and J.A. Dowdeswell. 2003. The distribution and flow characteristics of surge-type glaciers in the Canadian High Arctic. Ann. Glaciol., 36, 73-81.

Dowdeswell, J.A. 1995. Glaciers in the High Arctic and recent environmental change. Philos. Trans. R. Soc. London, Ser. A, 352(1699), 321-334. 
Dowdeswell, J.A. and 10 others. 1997. The mass balance of circum-Arctic glaciers and recent climate change. Quat. Res. 48(1), 1-14.

Driedger, C.L. and P.M. Kennard. 1986. Glacier volume estimation on Cascade volcanoes: an analysis and comparison with other methods. Ann. Glaciol., 8, 59-64.

Dyurgerov, M.B. and M.F. Meier. 2005. Glaciers and the changing Earth system: a 2004 snapshot. Boulder, CO, University of Colorado. Institute of Arctic and Alpine Research. (INSTAAR Occasional Paper 58.)

Evans, I.S. 2006. Local aspect asymmetry of mountain glaciation: a global survey of consistency of favoured directions for glacier numbers and altitudes. Geomorphology, 73(1-2), 166-184.

Farr, T.G. and 17 others. 2007. The Shuttle Radar Topography Mission. Rev. Geophys., 45(2), RG2004. (10.1029/ 2005RG000183.)

Granshaw, F.D. and A.G. Fountain. 2006. Glacier change (19581998) in the North Cascades National Park Complex, Washington, USA. J. Glaciol., 52(177), 251-256.

Grove, J.M. 2004. Little ice ages: ancient and modern. Second edition. London and New York, Routledge.

Haeberli, W. 1991. Alpengletscher im Treibhaus der Erde. Regio Basil., 32(2), 59-72.

Haeberli, W. and M. Hoelzle. 1995. Application of inventory data for estimating characteristics of and regional climate-change effects on mountain glaciers: a pilot study with the European Alps. Ann. Glaciol., 21, 206-212.

Haeberli, W., M. Hoelzle, F. Paul and M. Zemp. 2008. Correspondence. Integrated glacier monitoring strategies: comments on a recent correspondence. J. Glaciol., 54(188), 947-948.

Hoelzle, M., W. Haeberli, M. Dischl and W. Peschke. 2003. Secular glacier mass balances derived from cumulative glacier length changes. Global Planet. Change, 36(4), 295-306.

Jóhannesson, T., C.F. Raymond and E.D. Waddington. 1989. A simple method for determining the response time of glaciers. In Oerlemans, J., ed. Glacier fluctuations and climatic change. Dordrecht, etc., Kluwer Academic Publishers, 343-352.

Kääb, A., F. Paul, M. Maisch, M. Hoelzle and W. Haeberli. 2002. The new remote-sensing-derived Swiss glacier inventory: II. First results. Ann. Glaciol., 34, 362-366.

Kaser, G., J.G. Cogley, M.B. Dyurgerov, M.F. Meier and A. Ohmura. 2006. Mass balance of glaciers and ice caps: consensus estimates for 1961-2004. Geophys. Res. Lett., 33(19), L19501. (10.1029/2006GL027511.)

Maisch, M. 1981. Glazialmorphologische und gletschergeschichtliche Untersuchungen im Gebiet zwischen Landwasser- und Albulatal (Kt. Graubünden, Schweiz). Zürich, Universität Zürich. Geographisches Institut.

Meier, M.F. and 7 others. 2007. Glaciers dominate eustatic sea-level rise in the 21 st century. Science, 317(5841), 1064-1067.

Moritz, R.E., C.M. Bitz and E.J. Steig. 2002. Dynamics of recent climate change in the Arctic. Science, 297(5586), 1497-1502.

Oerlemans, J. 2005. Extracting a climate signal from 169 glacier records. Science, 308(5722), 675-677.

Ohmura, A., P. Kasser and M. Funk. 1992. Climate at the equilibrium line of glaciers. J. Glaciol., 38(130), 397-411.
Ommanney, C.S.L. 1980. The inventory of Canadian glaciers: procedures, techniques, progress and applications. IAHS Publ. 126 (Workshop at Riederalp 1978 - World Glacier Inventory), $35-44$.

Ommanney, C.S.L. 2009. Canada and the World Glacier Inventory. Ann. Glaciol., 50(53) (see paper in this issue).

Paterson, W.S.B. 1994. The physics of glaciers. Third edition. Oxford, etc., Elsevier.

Paul, F. 2007. The new Swiss glacier inventory 2000 - application of remote sensing and GIS. Schriftenreihe Physische Geographie, Univ. Zürich, 52.

Paul, F. and A. Kääb. 2005. Perspectives on the production of a glacier inventory from multispectral satellite data in Arctic Canada: Cumberland Peninsula, Baffin Island. Ann. Glaciol., 42, 59-66.

Paul, F., A. Kääb, M. Maisch, T. Kellenberger and W. Haeberli. 2002. The new remote-sensing-derived Swiss glacier inventory. I. Methods. Ann. Glaciol., 34, 355-361.

Paul, F., A. Kääb, M. Maisch, T. Kellenberger and W. Haeberli. 2004. Rapid disintegration of Alpine glaciers observed with satellite data. Geophys. Res. Lett., 31(21), L21402. (10.1029/ 2004GL020816.)

Permanent Service on the Fluctuations of Glaciers (PSFG). 1973. Fluctuations of glaciers 1965-1970 (Vol. II), ed. Kasser, P. Paris, International Commission on Snow and Ice of the International Association of Scientific Hydrology/UNESCO.

Racoviteanu, A.E., Y. Arnaud, M.W. Williams and J. Ordoñez. 2008. Decadal changes in glacier parameters in the Cordillera Blanca, Peru, derived from remote sensing. J. Glaciol., 54(186), 499-510.

Rahmstorf, S. 2007. A semi-empirical approach to projecting future sea-level rise. Science, 315(5810), 368-370.

Raper, S.C.B. and R.J. Braithwaite. 2006. Low sea level rise projections from mountain glaciers and ice caps under global warming. Nature, 439(7074), 311-313.

Raup, B. and 11 others. 2007. Remote sensing and GIS technology in the Global Land Ice Measurements from Space (GLIMS) Project. Comput. Geosci., 33(1), 104-125.

Svoboda, F. and F. Paul. 2009. A new glacier inventory on southern Baffin Island, Canada, from ASTER data: I. Applied methods, challenges and solutions. Ann. Glaciol., 50(53) (see paper in this issue).

Toutin, T. 2006. Generation of DSMs from SPOT-5 in-track HRS and across-track HRG stereo data using spatiotriangulation and autocalibration. ISPRS J. Photogramm. Remote Sens., 60(3), $170-181$.

Toutin, T. 2008. ASTER DEMs for geomatic and geoscientific applications: a review. Int. J. Remote Sens., 29(7), 1855-1875.

World Glacier Monitoring Service (WGMS). 1989. World glacier inventory: status 1988, ed. Haeberli, W., H. Bösch, K. Scherler, G. Østrem and C.C. Wallén. Zürich, IAHS(ICSI)-UNEP-UNESCO, World Glacier Monitoring Service.

WGMS. 2007. Glacier Mass Balance Bulletin No. 9 (2004-2005), ed. Haeberli, W., M. Zemp and M. Hoelzle. ICSU (FAGS)/IUGG (IACS)/UNEP/UNESCO/WMO, World Glacier Monitoring Service, Zürich.

Yde, J.C. and N.T. Knudsen. 2007. 20th-century glacier fluctuations on Disko Island (Qeqertarsuaq), Greenland. Ann. Glaciol., 46, 209-214. 